Economic and Environmental Geology

Research Paper

\title{
Transfer of Arsenic from Paddy Soils to Rice Plant under Different Cover Soil Thickness in Soil Amendments in Abandoned Coal Mine
}

\author{
Il-Ha Koh ${ }^{1}$, Yo Seb Kwon ${ }^{1,2}$, Mun-Ho Jeong ${ }^{3}$, Ju In Ko ${ }^{3}$, Gwan-In Bak ${ }^{3}$, Won Hyun Ji ${ }^{3,4 *}$ \\ ${ }^{1}$ National Environment Lab. (NeLab), Seoul, 02841, Korea \\ ${ }^{2}$ Department of Energy and Mineral Resources Engineering, Sejong University, Seoul 05006, Korea \\ ${ }^{3}$ Institute of Mine Reclamation Technology, Mine Reclamation Corporation, Wonju 26464, Korea \\ ${ }^{4}$ Department of General Education for Human Creativity, Hoseo University, Asan 31499, Korea \\ *Corresponding author : greenidea@hoseo.edu
}

\section{ARTICLE INFORMATION}

Manuscript received 26 August 2021

Manuscript accepted 27 August 2021

Available online 31 August 2021

DOI : http://dx.doi.org/10.9719/EEG.2021.54.4.483

\section{Research Highlights}

- As concentrations of farmland soil in abandoned coal mine area are generally low or about worrisome level $(25 \mathrm{mg} / \mathrm{kg})$.

- The properties of soil solution in contaminated or stabilized soil rarely affected that in cover soil.

- The thickness of clean cover soil layer could be reduced to $20 \mathrm{~cm}$ in soil amendment with As stabilization.

\begin{abstract}
This study was carried out to investigate the feasibility of reducing clean cover soil using a flooded column test in arseniccontaminated farmland reclamation of abandoned coal mine area that shows generally low or about worrisome level (25 mg/kg) of Korea soil environment conservation act unlike abandoned metal mine. During the monitoring period of soil solution for 4 months, chemical properties ( $\mathrm{pH}, \mathrm{EC}, \mathrm{ORP}, \mathrm{Fe}, \mathrm{Mn}, \mathrm{Ca}$, and As) in each layer (clean soil cover and contaminated/stabilized soil) showed different variation. This result revealed that soil solution in stabilized or contaminated soil rarely affected that in cover soil. Whether stabilized or not, arsenic concentrations in the rice roots grown in the soil covers with the thickness of $40 \mathrm{~cm}$ decreased by $98 \%$ in compared with the that grown in the control soil. In case of the soil covers with $20 \mathrm{~cm}$ thickness on stabilized soil, it decreased by $80 \%$ and this was 22 percentage point higher than when the soil of lower layer was not stabilized. Thus, reducing clean cover soil could be possible in contaminated farmland soil reclamation if appropriate stabilization of contaminated soil is carried.
\end{abstract}

Keywords: abandoned coal mine, As, paddy, rice, soil cover thickness

Citation: Koh, I.-H., Kwon, Y.S., Jeong, M.-H., Ko, J.I., Bak, G.-I., Ji, W.H. (2021) Transfer of Arsenic from Paddy Soils to Rice Plant under Different Cover Soil Thickness in Soil Amendments in Abandoned Coal Mine. Korea Economic and Environmental Geology, v.54, p.483-494, doi:10.9719/EEG2021.54.4.483.

This is an Open Access article distributed under the terms of the Creative Commons Attribution Non-Commercial License (http://creativecommons.org/ licenses/by-nc/3.0) which permits unrestricted non-commercial use, distribution, and reproduction in any medium, provided original work is properly cited. pISSN 1225-7281; eISSN 2288-7962/@2021 The KSEEG. Printed by Hanrimwon Publishing Company. All rights reserved. 


\title{
연구논문
}

\section{폐탄광지역 비소오염 농경지(논) 개량 시 복토두께에 따른 비소의 벼 전이 및 토양용액 특성}

\author{
고일하 ${ }^{1} \cdot$ 권요셉 ${ }^{1,2} \cdot$ 정문호 $^{3} \cdot$ 고주인 $^{3} \cdot$ 박관인 $^{3} \cdot$ 지원현 ${ }^{3,4 *}$
}

${ }^{1}$ 환경기술정책연구원 (NeLab), ${ }^{2}$ 세종대학교 에너지자원공학과, ${ }^{3}$ 한국광해관리공단 기술연구소, ${ }^{4}$ 호서대학교 창의교양학부

*책임저자 : greenidea@hoseo.edu

\section{요 약}

본 연구에서는 폐금속광산과는 달리 우려기준 전후의 낮은 비소 오염농도 분포특성을 가지는 폐석탄광산 농경지 토양을 대상 으로 광해방지사업(토양개량.복원사업) 시 복토층의 두께 감소 가능여부를 벼를 식재한 담수형 컬럼실험을 통해 검토하였다. 담수 후 4 개월 동안 토양용액의 $\mathrm{pH}, \mathrm{EC}, \mathrm{ORP}$ 및 무기원소 $(\mathrm{Fe}, \mathrm{Mn}, \mathrm{Ca}, \mathrm{As})$ 농도를 모니터링한 결과 컬럼하층에서 상층으로 미 치는 영향은 높지 않은 것으로 나타났다. 복토 두께에 따른 비교에서도 하층의 영향보다는 복토층 두께 변화에 따른 ORP 변화 가 복토재 무기원소의 거동에 영향을 미치는 결과를 보였다. 이러한 결과는 토양용액의 거동이 상하층간 반응의 영향보다는 각 층별 나타나는 토양의 이질성에 우선하여 나타난 것으로 판단되었다. 모니터링 종료시점에서 채취한 벼 뿌리의 비소 농도는 현 행 사업 조건과 같은 $40 \mathrm{~cm}$ 두께의 복토층을 조성한 경우 컬럼하층의 안정화 처리여부에 상관없이 대조구 대비 $98 \%$ 가 감소되 었다. $20 \mathrm{~cm}$ 두께의 복토층에서는 오염토의 안정화가 없을 경우 $58 \%$, 안정화처리 시 $80 \%$ 의 전이감소 효율을 나타내었다. 따라 서 오염 농경지 토양에 대한 적정 안정화 처리를 수행할 경우 복토재의 사용량을 감소시킬 수 있으며, 경제적인 사업수행효과 도 이룰 수 있을 것으로 판단된다.

주요어 : 폐석탄광산, 비소, 논, 벼, 복토 두께

\section{1. 서 론}

광산활동이 있었던 지역에는 무기 오염물질을 함유한 다양한 형태의 오염원이 존재한다. 이러한 오염원에는 매 질의 종류에 따라서 고상의 광폐석이나 광미 등의 광물 찌꺼기, 액상의 갱내수 등이 포함된다(Navarro et al., 2008). 따라서 오염원의 이동이나 확산에 의해 광산 주변에서 발생하는 오염도 다양하게 나타난다. 고농도 오염물질을 함유한 갱내수는 주변 수계에 유입되어 수생태계에 악영 향을 준다. 또한, 수계합류에 따른 $\mathrm{pH}$ 변화로 철 $(\mathrm{Fe})$ 이나 알루미늄 $(\mathrm{Al})$ 산화에 의한 적화나 백화침전을 일으켜 시 각적 불쾌감을 유발할 수도 있다(Kwon and Nam, 2013). 아울러 갱내수가 유입된 하천수의 농업용수 활용이나 광 물찌꺼기의 유실로 인해 농경지 토양오염이 발생하기도 한다. 이 경우 농작물의 생육에 지장을 초래하거나 오염 물질을 고농도로 함유하는 농산물이 생산될 가능성이 높 다( $\mathrm{Li}$ et al., 2014).

광산은 크게 금속광과 비금속광, 석탄광으로 구분할 수 있다. 금속광은 철, 연·아연, 텅스텐 등을, 비금속광은 석 회석, 규석, 장석 등을 주요 채굴대상 광종으로 한다. 이 중 수질오염이나 토양오염의 관점에서 문제시 되고 있는
광산은 금속광과 석탄광이다. 다만, 이들 광산의 고상 오 염원은 그 종류가 다르게 나타난다. 금속광에서는 목적 금속을 추출하고 남은 광물찌꺼기가, 석탄광에서는 경석 이 오염원이라 할 수 있다. 아울러 갱내수의 경우엔 석 탄광보다는 금속광의 위해성이 높은데, 금속광산의 갱내 수 수량은 비교적 적으나 중금속 등의 함량이 석탄광보 다 높다(Jung et al., 2008). 이에 따라서 광산 주변 농경 지 토양오염의 수준도 광산의 종류에 따라 다르게 나타 난다. 금속광과 석탄광 모두 오염관측 빈도가 높은 항목 이 비소(As)로 나타나는 공통점이 있다. 그러나 석탄광에 서의 비소오염 수준은 금속광에 비해 낮다. 2014년부터 2018년까지 환경부에서 실시한 폐석탄광산 토양오염실태 정밀조사 결과에서는 비소오염이 확인된 토양시료의 대 부분인 $44 \%$ 가 $35 \mathrm{mg} / \mathrm{kg}$ 미만이며, 대책기준 $(75 \mathrm{mg} / \mathrm{kg})$ 을 초과한 비율은 $9 \%$ 에 불과한 실정으로 확인되었다 (Kwon et al., 2021). 즉, 비소의 농경지 토양오염 농도가 대체적으로 우려기준(농경지 $25 \mathrm{mg} / \mathrm{kg}$ )을 조금 넘는 일 관적인 수치를 보였다고 할 수 있다. 금속광산의 경우 특 정 금속만을 회수하기 위한 선광, 제련과정에서 발생하 는 광물찌꺼기의 영향으로 토양오염에 미치는 영향이 석 탄광산이 비해 높은 것으로 알려졌다(Kwon and Nam, 
2013). Jung and Jung(2006)의 연구에서도 2004년 2005 년 환경부의 687 개 휴폐금속광산 개황조사 결과를 검토 한 결과 165 개 시료에서 비소가 우려기준 $(25 \mathrm{mg} / \mathrm{kg})$ 을 초과했으나 이중 111 개가 대책기준 $(75 \mathrm{mg} / \mathrm{kg}$ )까지 초과 했을 정도로 높은 고농도 토양오염 빈도을 확인한 바 있다.

국내에서는 광산지역 주변 오염농경지에 대해 광해방 지사업의 일환으로 토양개량-복원공법을 적용해 오고 있 다. 본 공법은 기존의 오염된 경작층에 안정화제를 처리 하여 $20 \mathrm{~cm}$ 두께의 안정화층을 형성하고, 상부에 비오염 경작층(복토층)을 $40 \mathrm{~cm}$ 두께로 구성하는 방식이다(Kim et al., 2019). 즉, 오염토양 내 오염물질의 이동성을 낮춰 농작물로의 전이를 최대한 억제하는 것이 근본적인 목적 이라 할 수 있다. 따라서 상부 비오염 복토층 조성을 위 해서는 농작물 재배에 적합한 점토함량이나 기타 이화학 적 특성을 고려한 적정수준의 토양확보가 필요하다. 그 러나 일선 사업현장에서는 이러한 적정 품질의 복토재 확보에 상당한 어려움이 있어 공사비 증가의 주요 원인 으로 작용하고 있다. 광산지역 토양개량-복원사업의 시 작이 빨랐던 일본에서도 복토재 수급의 어려움으로 인해 이를 대체하기 위해 원위치세척기술이 연구되기도 했다 (Makino et al., 2016; Makino et al., 2008; Makino et al., 2007). 앞서 언급했듯이 폐석탄광산 지역에서 나타나는 비소의 토양 내 농도는 토양오염우려기준 전후로 폐금속 광산 지역에 비해 상대적 저농도이다. 따라서 이동성을 가지는 비소의 농도 역시 낮을 것으로 예상된다. 물론, 비소의 전함량 농도가 낮다고 이동성 함량이 비율도 낮 다고 할 수는 없다. 그러나 전함량 농도의 수준이 우려 기준을 전후로 나타나는 상대적 저농도라면, 이동성 비 소의 함량 역시 크지 않을 것이다. 이는 곧 식물체로 전 이되는 수준도 낮을 것으로 예상되므로 그만큼 복토층 두께의 탄력적 변화가 가능할 것임을 유추할 수 있다.

농경지 토양관점에서 그간의 광해방지사업은 주로 폐 금속광산 위주로 진행되어 왔다. 이는 광산주변에 미치 는 환경학적 악영향이 석탄광에 비해서 높았기 때문이다. 폐금속광산의 오염원은 광미, 광폐석 등의 광물찌꺼기와 갱내수로 다양하며, 오염물질의 부하량도 높다. 그러나 폐석탄광산 역시 토양오염으로 인한 문제가 지속적으로 확인되고 있어 최근들어 관련 광해방지사업이 시작되었 다. 다만, 앞서 언급한 바와 같이 폐금속광산의 토양오염 수준과는 다른 특성으로 인해 기존에 폐금속광산 현장에 적용하는 방식을 달리 적용해 볼 필요가 있을 것이다.

이에 본 연구에서는 폐석탄광산 주변 비소오염 농경지 를 대상으로 복토층의 두께를 감소시킨 토양개량-복원 공법의 적용성을 실제 벼를 재배하는 담수형 컬럼실험을 통해 검토하였다. 기존 폐금속광산 지역 대상의 토양개
량-복원 방식 즉, 안정화제 처리 후 상부 복토하는 방식 을 그대로 준용하되, 복토층의 두께만을 감소시키는 것 이다. 복토층의 두께를 감소시킬 수 있다면, 광해방지사 업 시 나타나는 적정한 복토재 확보의 어려움을 일정부 분 해소시킬 수 있을 것으로 판단된다. 아울러 이는 광 해방지사업의 경제성 확보에도 큰 도움을 줄 수 있을 것이다.

\section{2. 실험 방법 및 내용}

본 연구에서는 광해방지사업 대상 농경지(논)의 토양개 량-복원조건을 모사한 컬럼실험을 실시하였다. 오염된 경 작층의 안정화처리 후 상부 복토층의 두께를 달리하였을 때, 층별 나타나는 토양용액(soil solution) 특성의 경시변 화와 벼 재배를 통해 식물체로 전이된 오염물질(비소)의 함량을 확인하고자 하였다.

\section{1. 실험대상 토양채취 및 분석}

컬럼실험 대상 오염토양은 강원도 영월군 김삿갓면 소 재 폐석탄광산 주변지역의 농경지(논)에서 채취한 것이 었다. 토양채취 시 현장에서 바로 $5 \mathrm{~mm}$ 체질을 실시해 해당 크기 미만의 입자를 실험대상으로 하였다. 체질한 토양을 실험실 입고 후 균질하게 혼합하였고, 이후 17일 동안 자연건조하였다. 복토재로 사용한 비오염토양은 실 제 광해방지사업 현장의 복토재로, 원토취장은 경북 봉 화군 명호면 일대에 위치하였다. 복토재 역시 오염토양 과 동일한 일정으로 현장체질 및 자연건조를 실시하였다.

자연건조가 완료된 실험대상 토양을 대상으로 국내 토 양오염공정시험기준(NIER, 2018)에 의한 비소 및 무기원 소 4 개 항목 $(\mathrm{Cd}, \mathrm{Cu}, \mathrm{Pb}, \mathrm{Zn})$ 의 함량을 분석하였다. 이외 이화학 특성 $(\mathrm{pH}$, 유효인산, 유효규산, 양이온교환능, 교 환성 양이온 3 개 항목)도 분석하였는데, 토양화학분석법 (NAAS, 2010)에 의한 전처리를 준용하였다. 농도정량 시 무기원소는 ICP-OES(model 8300, Perkin-Elmer Inc.)를, 유효인산과 유효규산은 UV-VIS(model Lamda 25, PerkinElmer Inc.)를 이용하였다. 토양의 $\mathrm{pH}$ 는 휴대용 수질측정 기(model Orion Star A329, Thermo SCIENTIFIC Inc.)를 이용하여 측정하였다.

\section{2. 컬럼실험}

\subsection{1. 컬럼설치}

광산지역 농경지 광해방지사업(토양개량- 복원사업)의 모사를 위해 우선 내경 $13 \mathrm{~cm}$, 높이 $20 \mathrm{~cm}$ 의 아크릴 재 질의 컬럼에 건조무게 기준 $3.1 \mathrm{~kg}$ 의 오염토를 적재하였 다. 본 토양층의 상부에 컬럼을 추가설치하여 복토층을 조성하였다. 본 실험의 목적이 복토재 사용량 저감가능 
성 검토이므로, 통상적으로 적용되고 있는 $40 \mathrm{~cm}$ 두께(복 토재 $8.2 \mathrm{~kg}$ ) 이외 $20 \mathrm{~cm}$ 두께(복토재 $4.1 \mathrm{~kg}$ ) 조건을 추 가로 배치하였다. 아울러 오염물질의 안정화 유도를 위 해 비소 오염토와 안정화제를 혼합한 안정화층 조성 조 건도 추가로 배치하였다. 적용된 안정화제는 제강슬래그 로 국내 광해방지사업에서 일반적으로 사용되고 있는 제 철공정의 산업부산물이다. 재강슬래그의 투여량은 오염 토양의 무게비 대비 $3 \%$ 수준이었다. 컬럼 각 층(복토층, 오염토층/안정화층)의 중앙에는 담수토양 내 토양용액의 주기적인 채수를 위한 RHIZON Soil Moisture Sampler (Rhizosphere Research Products bv)를 설치하였다.

컬럼설치 후 바로 수돗물로 담수하였고, 1 일 경과 후 복 합화학비료 $1 \mathrm{~g}$ 을 투여하였다. 사용된 화학비료는 남해 화학에서 생산된 N-P-K 비료이었다. 웃거름으로 시비되 는 특성을 고려해 컬럼 최상단의 지표면으로부터 $10 \mathrm{~cm}$ 이내 심도구간에서 혼합하였다. 비료 투여 1 일 경과 후 실제 논토양 모사를 위해 육묘이식 방식으로 벼 모종(품 종: 오대)을 식재하였다. 식재수량은 컬럼당 1포기로 모 종 7 개 $~ 8$ 개로 구성되었다.

컬럼은 강우의 직접적인 영향을 받지 않는 실외에 배 치되었으며, 수돗물을 이용하여 상시 $5 \mathrm{~cm} \sim 10 \mathrm{~cm}$ 의 담수심도를 유지하도록 하였다. 벼 수확 15 일 이전에 담 수를 중단하였으며, 담수 유지기간은 107일이었다. Fig. 1 에 본 실험에 사용된 컬럼의 개요도를 나타내었다. Control 은 복토나 안정화 처리를 하지 않은 오염토양 그대로의 대조구이다. 이외 안정화 처리유무에 따라서 컬럼 $\mathrm{A}$ 타입 (안정화 처리없이 복토), 컬럼 $\mathrm{B}$ 타입(안정화 처리 후 복 토)으로 구분을 하였다. 각 컬럼별 분석결과 표기의 편의 를 위해 복토층은 U(upper layer), 원지반층/안정화층은 $\mathrm{L}$ (lower layer)로 표기했고, 뒤이어 복토층 두께를 표기하
였다. 즉, $\mathrm{AU} 20$ 과 $\mathrm{AL} 20$ 은 안정화 처리를 하지 않은 A 타입의 컬럼으로 $20 \mathrm{~cm}$ 의 복토층 두께를 가진 컬럼상층 (복토층)과 이의 하층(원지반층)을 의미한다.

\subsection{2. 시료채취}

컬럼실험 중 분석대상 검체는 토양용액과 식물체(벼)이 었다. 시간경과에 따른 토양용액 내 무기원소의 용출경 향을 파악하기 위해 최종 담수완료 5일 경과시점부터 토 양용액을 주 1 회 빈도로 총 17 회 채취하였다. 토양용액 은 앞서 언급한 RHIZON Soil Moisture Sampler를 주사 기에 연결해 압력강하를 시킨 후 감압작용에 의해 추출 된 수분으로 1 회 $30 \mathrm{~mL} \sim 55 \mathrm{~mL}$ 를 채취하였다. 채취한 토양용액을 대상으로 현장항목을 측정한 후 무기원소 기 기분석을 위해 수질오염공정시험기준(NIER, 2019)에 의 한 전처리(비소 및 중금속 항목에 한정해 산처리) 후 실 험실로 이송하였다.

대상 농작물인 벼는 쌀알과 뿌리로 구분하여 채취하였 다. 채취시점은 모종 식재 후 대략 115 일 전후이었다. 뿌 리는 대조구(control)를 제외한 나머지 조건에서 복토층 에 존재하는 부위를 채취대상으로 하였다. 채취 직후 세 척을 하여 뿌리표면에 흡착된 토양을 최대한 제거하였다.

\subsection{3. 시료분석}

컬럼 토양용액 채취직후 $0.45 \mu \mathrm{m}$ 여과 후 휴대용 현장 수질측정기(model Orion Star A329, Thermo SCIENTIFIC Inc.)를 이용하여 $\mathrm{pH}$, 전기전도도(electrical conductivity, $\mathrm{EC}$ ), 산화환원전위(oxidation/reduction potential, ORP)를 측정하였다. 산처리된 잔여 토양용액은 실험실 이송 후 수질오염공정시험기준(NIER, 2019)에 따라 분석을 실시 했는데, 대상 항목은 오염물질인 비소와 비소의 거동에

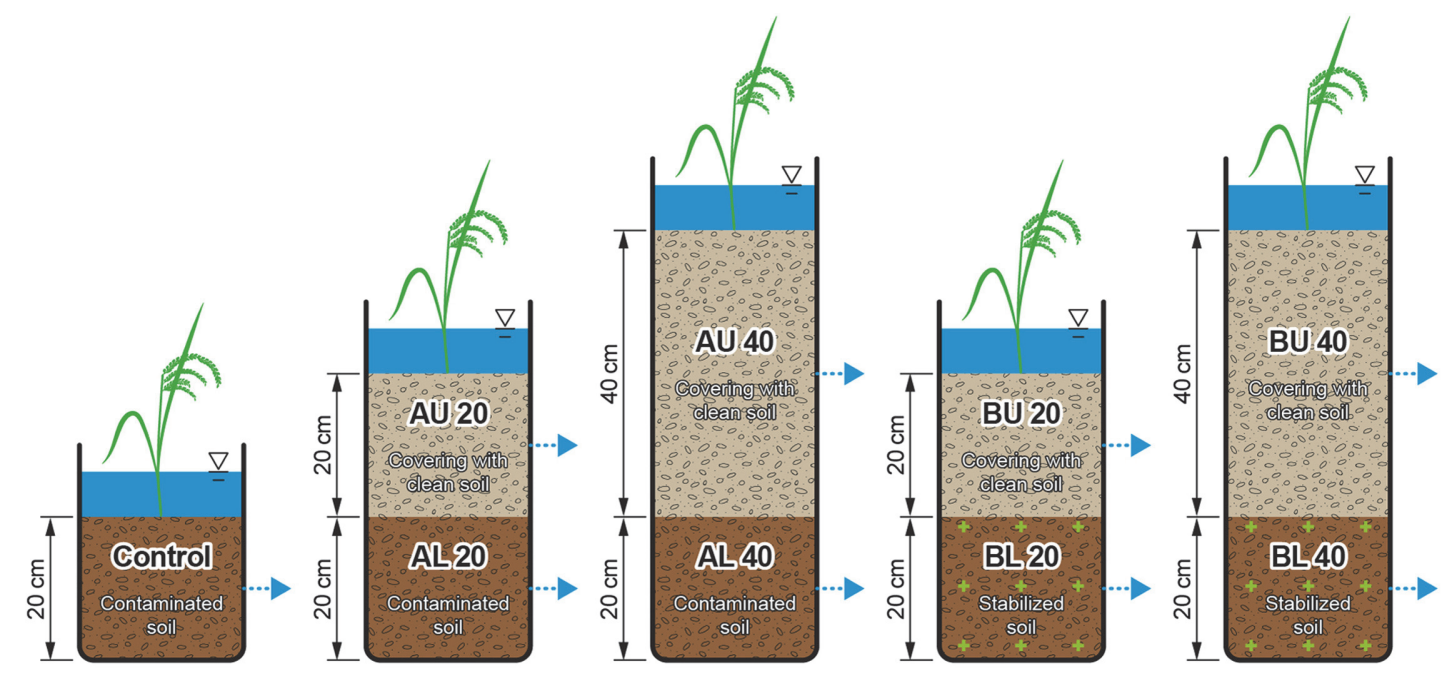

Fig. 1. The schematic diagram of column experiment. 
영향을 미칠 것으로 판단된 철, 망간 $(\mathrm{Mn})$, 칼슘 $(\mathrm{Ca})$ 등 총 4 개 항목이었다.

식물체인 벼(쌀알, 뿌리)를 대상으로 토양오염물질인 비소의 정량분석을 하였으며, 식품공전(MFDS, 2020)의 전처리 방식을 준용하였다. 다만, 쌀알의 경우 현미 (unpolished grain)를 분석대상으로 하였다. 이는 무기질 함량이 높은 쌀겨가 포함된 현미상태의 분석을 통해 토 양 오염물질(As)의 토양-식물체 전이수준 비교가 용이할 것으로 예상됐기 때문이다.

전처리가 완료된 토양용액과 식물체의 무기원소 정량 분석은 일차적으로 ICP-OES(model 8300, Perkin-Elmer Inc.)를 이용하였다. 일차 분석결과 정량한계 미만의 불검 출 수준의 결과가 도출된 경우, 정량한계가 상대적으로 낮은 ICP-MS(model iCAP Q, Thermo SCIENTIFIC inc.) 를 추가 이용하여 그 농도를 정량하였다.

\section{3. 결과 및 고찰}

\section{1. 실험대상 토양특성}

Table 1은 실험대상 토양의 비소 및 무기원소 4개 항 목 $(\mathrm{Cd}, \mathrm{Cu}, \mathrm{Pb}, \mathrm{Zn})$ 의 함량을 나타낸 것이다. 오염토양의 오염항목은 비소로 $33 \mathrm{mg} / \mathrm{kg}$ 의 농도를 나타내었다. 본 수치는 토양환경보전법에서 제시하는 농경지 우려기준 $(25 \mathrm{mg} / \mathrm{kg})$ 을 약간 상회하는 것이었다. 즉, 폐석탄광산 주변 농경지 비소농도의 대부분이 $35 \mathrm{mg} / \mathrm{kg}$ 미만을 보 인다는 Kwon et al.(2021)의 연구결과와 동일한 것으로, 비소오염 수준이 높지 않은 폐석탄광산 주변지역의 전형 적인 특성을 나타낸 것으로 볼 수 있다. 복토재의 비소
농도는 오염토양 대비 $25 \%$ 미만의 $6 \mathrm{mg} / \mathrm{kg}$ 으로 확인되었다. 대상 토양의 이화학 특성 분석결과는 Table 2에 나타난 바와 같다. 실험작물(벼)의 경작층이 될 복토재의 $\mathrm{pH}$ 는 6.8 의 약산성이었다. 이외 유효인산 $\left(\mathrm{P}_{2} \mathrm{O}_{5}\right)$ 농도는 $22 \mathrm{mg} / \mathrm{kg}$ 으로 논토양의 적정수준에는 부적합하여 컬럼설치 시 복 합비료를 시비처방 하였다. 복토재와 오염토의 점토함량 (토성)은 각각 $13 \%$ (사양토), $26 \%$ (사질식양토)이었다.

\section{2. 컬럼 토양용액 특성변화}

\subsection{1. 현장항목 거동특성}

Fig. 2는 담수컬럼 운영 중 채취한 토양용액의 $\mathrm{pH}, \mathrm{EC}$, $\mathrm{ORP}$ 경시변화를 각 층별 2주 간격의 평균값으로 나타낸 것이다. Fig. 1에서 확인할 수 있듯이 대조구를 제외한 조건의 컬럼 상층은 $20 \mathrm{~cm}$ 및 $40 \mathrm{~cm}$ 의 복토두께, 하층 은 안정화 처리유무로 구분할 수 있다.

모니터링 기간 중 토양용액의 $\mathrm{pH}$ 는 컬럼 상하층에 상 관없이 대체적으로 증가하는 경향을 나타내었다. 이는 담 수된 토양의 공통적인 특성으로 판단된다. 토양이 담수 되면 토양 미생물 호흡의 영향으로 축적된 중탄산이온 $\left(\mathrm{HCO}_{3}{ }^{-}\right)$에 의해 토양자체의 $\mathrm{pH}$ 와 상관없이 중성의 수준 으로 유지된다. 이는 중탄산이온이 토양용액 내 환원성 양이온중금속 $\left(\mathrm{Fe}^{2+}, \mathrm{Mn}^{2+}\right)$ 과 우선적으로 반응하기 때문에 칼슘이온 $\left(\mathrm{Ca}^{2+}\right)$ 과 같은 소모되지 않은 교환성 이온에 의 해 $\mathrm{pH} 6.5$ 7의 범위로 증가하기 때문이다(Kirk, 2004; Meharg and Zaho, 2012). 본 실험에서도 알칼리 안정화 제 투여가 없었던 오염토층(AL 20, AL 40)과 이의 복토 층(AU 20, $\mathrm{AU} 40)$ 을 보면 이러한 $\mathrm{pH}$ 증가경향은 더 명 확하게 확인된다. 아울러 안정화제 종류를 달리하며 안

Table 1. The concentrations of inorganic contaminants of the studied soils

\begin{tabular}{cccccccc}
\hline & & \multicolumn{5}{c}{ Conc. (Mean \pm SD, mg/kg) } \\
\cline { 3 - 7 } & & As & Cd & $\mathrm{Cu}$ & $\mathrm{Pb}$ & $\mathrm{Zn}$ \\
\hline \multirow{2}{*}{ Standard $^{(1)}$} & Worrisome & 25 & 4 & 150 & 200 & 300 \\
\cline { 2 - 7 } & Countermeasure & 75 & 12 & 450 & 600 & 900 \\
\hline \multicolumn{2}{c}{ Cover Soil } & $5.60 \pm 0.12$ & $\mathrm{ND}^{(2)}$ & $1.49 \pm 0.34$ & $13.09 \pm 0.05$ & $129.01 \pm 11.69$ \\
\hline \multicolumn{2}{c}{ Contaminated Soil } & $32.95 \pm 1.29$ & $\mathrm{ND}^{(2)}$ & $31.08 \pm 1.59$ & $23.79 \pm 1.11$ & $66.05 \pm 04.61$ \\
\hline
\end{tabular}

(1) Criteria for agricultural soil from soil environment conservation act of Korea

(2) Not Detected

Table 2. The chemical properties of the studied soils

\begin{tabular}{|c|c|c|c|c|c|c|c|}
\hline & \multirow{2}{*}{$\mathrm{pH}$} & \multirow{2}{*}{$\begin{array}{c}\text { Av. }-\mathrm{P}_{2} \mathrm{O}_{5} \\
(\mathrm{mg} / \mathrm{kg})\end{array}$} & \multirow{2}{*}{$\begin{array}{c}\text { Av.-SiO } \\
(\mathrm{mg} / \mathrm{kg})\end{array}$} & \multirow{2}{*}{$\begin{array}{c}\mathrm{CEC} \\
\left(\mathrm{cmol}_{\mathrm{c}} / \mathrm{kg}\right)\end{array}$} & \multicolumn{3}{|c|}{ Exchangeable cation $\left(\mathrm{cmol}_{\mathrm{c}} / \mathrm{kg}\right)$} \\
\hline & & & & & $\mathrm{Ca}$ & $\mathrm{Mg}$ & K \\
\hline Acceptable range ${ }^{(1)}$ & $6.0 \sim 6.5$ & $80 \sim 120$ & $130 \sim 180$ & - & $5.0 \sim 6.0$ & $1.5 \sim 2.5$ & $0.25 \sim 0.30$ \\
\hline Cover soil & $6.8 \pm 0.0$ & $22.41 \pm 1.58$ & $145.91 \pm 8.05$ & $13.80 \pm 0.45$ & $7.23 \pm 0.29$ & $1.39 \pm 0.06$ & $0.33 \pm 0.04$ \\
\hline Contaminated soil & $5.0 \pm 0.0$ & $114.00 \pm 1.29$ & $97.01 \pm 5.50$ & $9.78 \pm 0.32$ & $2.37 \pm 0.12$ & $0.61 \pm 0.02$ & $0.40 \pm 0.02$ \\
\hline
\end{tabular}



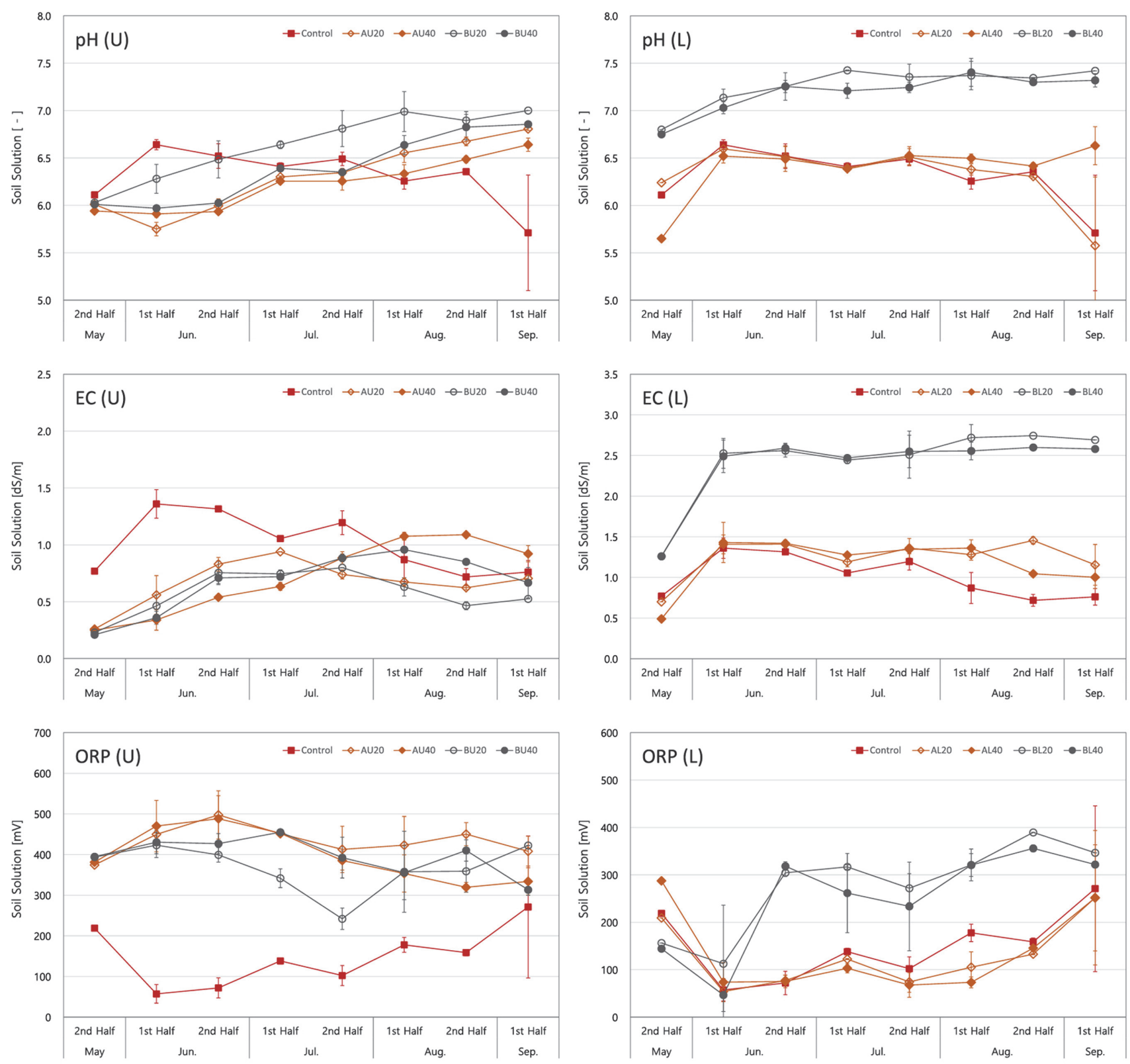

Fig. 2. The variation of pH, EC and ORP in soil solution ((U) upper layer, clean soil cover; (L) lower layer, contaminated or stabilized layer).

정화 처리한 논토양의 토양용액 이화학적 특성변화를 모 니터링한 Koh et al.(2015a)의 연구에서도 동일한 결과를 확인한 바 있다.

컬럼 하층에서는 대조구와 안정화 처리가 없었던 2개 조건(AL 20, $\mathrm{AL} 40)$ 에서 모니터링 초기와 종료시점을 제외하면 $\mathrm{pH} 6.5$ 전후의 수치를 보였다. 이에 비해 안정 화제 처리조건(BL 20, BL 40)에서는 $\mathrm{pH} 7.0$ 7.5의 범 위로 상대적으로 높게 나타났다. 이는 안정화제로 사용 된 제강슬래그의 영향으로 볼 수 있다. 제강슬래그는 철 생산과정에서 발생하는 부산물로 철분 $\left(\mathrm{Fe}, \mathrm{FeO}, \mathrm{Fe}_{2} \mathrm{O}_{3}\right)$
과 함께 $\mathrm{CaO}$ 함량이 높은 알칼리 물질이며, 일부 인산 $\left(\mathrm{P}_{2} \mathrm{O}_{5}\right)$ 도 함유하는 것으로 알려졌다(Lim et al., 2010). 따 라서 알칼리 물질의 용탈로 인해 미생물 호흡 영향보다 더 높은 $\mathrm{pH}$ 증가가 발생했던 것으로 판단된다. 이러한 $\mathrm{pH}$ 증가는 컬럼 상층에도 영향을 주었던 것으로 보이는 데, 해당 조건의 복토층(BU 20, BU40)에서도 타 조건 대 비 미세하게 높은 수치가 확인되었다. 특히, 복토층의 두 께가 $20 \mathrm{~cm}$ 인 조건(BU 20)에서 $40 \mathrm{~cm}$ 인 조건(BU 40) 에 비해 $\mathrm{pH}$ 가 높았음을 고려하면, 컬럼 하층으로부터의 용탈물질 영향을 쉽게 받았던 것으로 판단된다. 
$\mathrm{EC}$ 는 컬럼 하층에서 모니터링 초기를 제외하면 안정 화 조건(BL $20, \mathrm{BL} 40)$ 에서 $2.6 \mathrm{dS} / \mathrm{m}$ 전후, 이외 조건에 서 $1.5 \mathrm{dS} / \mathrm{m}$ 미만으로 확인되었다. $\mathrm{pH} 8.5$ 미만의 염류 토양으로서 식물성장에 악영향을 줄 수 있는 $\mathrm{EC}$ 의 범위 는 $4 \mathrm{dS} / \mathrm{m}$ 이상이다(Brady and Weil, 2014). 따라서 EC를 기준으로 봤을 때 본 안정화층의 토양용액이 식물성장에 미친 악영향은 없었던 것으로 보인다. 안정화 조건에서 나타난 상대적으로 높은 수치는 앞서 언급한 바와 같이 제강슬래그로부터 토양공극 수분으로 용탈된 이온의 영 향일 것이다. 아울러 제강슬래그의 칼슘함량이 높은 만 큼 칼슘이온의 영향이 높았던 것으로 판단된다.

컬럼 상층에서 나타난 $\mathrm{EC}$ 의 경시변화는 컬럼하층과 유 사하게 나타나지 않았다. 이는 상하층 토양의 이질성과 함께 하층 토양용액의 이화학 변화가 상층 토양용액에 미치는 영향이 제한적이었음을 보인 결과로 판단된다. 복 토층 두께에 따른 $\mathrm{EC}$ 비교에서는 모니터링 중후반 시점 부터 컬럼 하층의 안정화 처리유무에 상관없이 복토 $40 \mathrm{~cm}$ $>$ 복토 $20 \mathrm{~cm}$ 의 경향을 보였다. 이 같은 결과는 뒤에 언 급할 망간과 칼슘의 용탈영향으로 판단된다. 즉, $40 \mathrm{~cm}$ 두께의 복토층은 $20 \mathrm{~cm}$ 복토층에 비해 지표면으로부터 의 두께가 크므로 토양용액의 산화환원전위 감소가 상대 적으로 컸으며, 이에 따라 망간의 환원 용출농도 역시 높 게 나타났다고 볼 수 있다. 또한 용출된 망간이온 $\left(\mathrm{Mn}^{2+}\right)$ 이 토양입자 표면의 칼슘과 이온교환을 통해 칼슘이온 $\left(\mathrm{Ca}^{2+}\right)$ 의 증가를 유도했을 것이다(He et al., 2010).

철, 망간, 비소 등 환원성 물질의 이동성을 간접적으로 평가할 수 있는 ORP는 컬럼 상층에서 높게, 하층에서 낮 게 나타났다. 대조구의 토양용액은 지표로부터 $10 \mathrm{~cm}$ 아 래에서 채취한 것이었다. 따라서 복토층의 ORP와 유사 할 것으로 예상되었으나 실제 측정결과 상당히 낮은 수 치를 보였다. 모니터링 시작 및 종료 시점을 제외한 대 조구의 $\mathrm{ORP}$ 는 $200 \mathrm{mV}$ 미만이이었다. 이에 비해 복토층 (컬럼 상층)에서 측정된 $\mathrm{ORP}$ 는 대체적으로 $300 \mathrm{mV}$ $500 \mathrm{mV}$ 범위였다. 이 같은 결과는 복토재보다 미생물 증 식에 용이한 조건을 가진 대조구 토양 특성에 기인한 것 으로 판단된다. 앞선 Table 2에 나타난 바와 같이 원토양 (오염토양)의 유효인산 함량은 $114 \mathrm{mg} / \mathrm{kg}$ 으로 복토재 $(22 \mathrm{mg} / \mathrm{kg})$ 보다 5 배 넘는 것으로 나타났다. 아울러 점토 함량이 복토재보다 높은 사질식양토로 토양 미생물 증식 에 유리한 환경이 조성되어 그만큼 산소 소비도 높았던 것으로 판단된다.

컬럼 하층에서의 ORP 변화는 안정화 처리유무에 따른 차이가 명확하게 나타났다. 일반적으로 동일한 지질조건 이라면 심부로 내려갈수록 $\mathrm{ORP}$ 는 감소할 것이다. 이는 산소의 포화도가 낮아지는 환원환경으로 변화하기 때문
이다(Sparks, 1995). 그러나 본 실험에서는 제강슬래그 처 리조건에서 6월 중반 이후 $300 \mathrm{mV}$ 전후의 수치를 보였 다. 이는 6월 8월에 타 조건에서 보인 $200 \mathrm{mV}$ 미만의 수치와 비교할 때도 ORP 감소수준이 높지 않았음을 나 타낸 것이다. 이 같은 결과는 제강슬래그 내 철의 영향 으로 보인다. 담수 토양에서의 토양미생물은 산소가 소 모된 이후 다른 원소(화합물)를 전자수용체로 활용한다. 일반적인 활용순서는 망간, 철, 황 $(\mathrm{S})$ 이며, 진행 중에 $\mathrm{ORP}$ 는 지속적으로 감소한다(Pierzynski et al., 1994). 따라서 본 실험에서 나타난 안정화 처리층의 타조건 대비 높은 $\mathrm{ORP}$ 수치는 미생물이 토양자체의 철이 아닌 제강슬래그 내 철을 전자수용체로 활용하면서 $\mathrm{ORP}$ 의 감소가 완화된 것 때문으로 판단된다. 토양오염물질인 비소는 철이나 망 간과 같이 환원환경에서 이동성이 증가하는 환원성 물질 이다. 따라서 지중 제강슬래그를 투여를 통해 ORP 감소 를 유도한다면 비소의 이동성을 감소시킬 수 있을 것으 로 판단된다. 이와 비슷한 사례로 논토양의 배수조건 조 절을 통해 산화/환원 환경을 조절하여 비소나 카드뮴의 전이를 억제하는 방안이 검토되기도 하였다(Koh et al., 2017; Nakamura and Katou, 2013).

컬럼 상층의 두께 차이에 따른 $\mathrm{ORP}$ 의 경시변화는 안 정화처리 유무에 따라 다른 특성변화를 보였다. 하부 원 지반층에 안정화처리를 하지 않고 복토층을 두껍게 한 경우(AU 40) 모니터링 중후반에 ORP가 감소하는 것으 로 나타났다. 그러나 안정화층 상부의 복토층에서는 복 토 두께가 얇은 경우(BU 20) ORP가 상대적으로 낮게 나 타났다. 이는 앞선 $\mathrm{pH}$ 와 마찬가지로 얇은 두께의 복토층 특성상 컬럼 하층의 영향을 쉽게 받은 것으로 보인다. 즉, 제강슬래그 기원의 인 $(\mathrm{P})$ 이 복토층 내 미생물 활성에 영 향을 주어 산소 소모가 그만큼 증가했기 때문으로 판단된다.

\subsection{2. 무기원소 거동특성}

Fig. 3은 앞서 현장항목을 측정했던 동일한 토양용액을 대상으로 오염물질인 비소와 비소의 거동에 영향을 미치 는 무기원소로 알려진 철, 망간, 칼슘의 농도변화를 나타 낸 것이다. 본 결과 역시 컬럼의 각 층에서 채취한 토양 용액 분석결과를 2 주 간격의 평균값으로 나타내었다.

환원성 중금속인 철과 망간은 안정화층에서 타 조건 대 비 낮은 용출농도를 나타내었다. 이는 알칼리 안정화제 적용으로 인한 양이온 중금속의 침전으로 해석할 수 있 다(Zhu et al., 2014). Koh et al.(2015a), Koh et al.(2015b), Yun et al.(2011)의 연구에서도 환원성 중금속이라도 환 원환경에 따른 용탈보다는 알칼리 침전이 우선하는 결과 를 확인한 바 있다. 층별 용출농도는 망간보다는 철에서 그 경향의 차이가 확연하게 나타났다. 망간은 컬럼 상층 

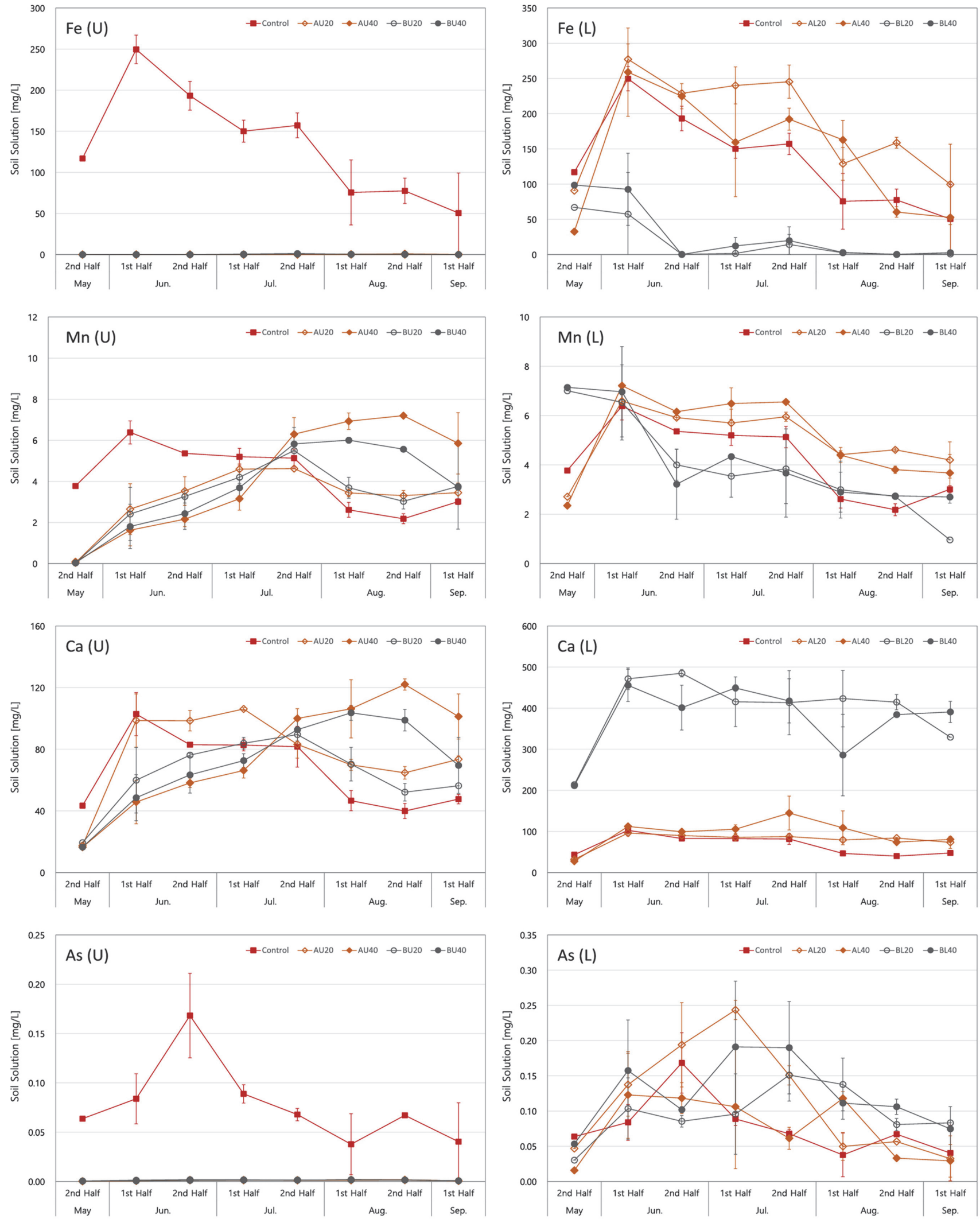

Fig. 3. The variation of $\mathrm{Fe}, \mathrm{Mn}, \mathrm{Ca}$ and $\mathrm{As}$ in soil solution ((U) upper layer, clean soil cover; (L) lower layer, contaminated or stabilized layer). 
과 하층 모두 $2 \mathrm{mg} / \mathrm{L} \sim 10 \mathrm{mg} / \mathrm{L}$ 의 범위를 보였다. 그러 나 철은 대조구를 제외하면 컬럼 상하층간 용출농도의 차이가 큰데, 하층에서 대략 $250 \mathrm{mg} / \mathrm{L}$ 미만, 컬럼 상층 에서 $3 \mathrm{mg} / \mathrm{L}$ 로 나타났다. 이러한 결과는 컬럼 상하층에 서 확인되는 산화환원전위의 차이에 기인한다고 볼 수 있다. 즉, 토양미생물의 전자수용체 선택성에 기인한 것 이다. 미생물은 담수된 토양에서 전자수용체로 산소를 우 선 소모한 이후 $\mathrm{NO}_{3}-\mathrm{N}^{-}, \mathrm{Mn}^{4+}, \mathrm{Fe}^{3+}$ 와 같은 무기물을 순 차적으로 사용한다. 특히, 철·망간 환원 발생시점의 산화 환원전위는 각각 $120 \mathrm{mV}$ 및 $200 \mathrm{mV}$ 로 알려졌다(Pierzynski et al., 1994). 따라서 모니터링 중반 컬럼하층 안정화 처리 가 없었던 2개 조건(AL 20, $\mathrm{AL} 40)$ 에서 나타난 산화환원 전위가 $100 \mathrm{mV}$ 전후였음을 고려하면, 본 시기 $200 \mathrm{mg} / \mathrm{L}$ 전후의 높은 철 농도는 전형적인 담수토양의 특성을 보 였다고 할 수 있다.

복토를 한 상황에서 상·하층간 철·망간 농도의 경시변 화는 뚜렷한 유사성을 보이지 않았다. 앞선 $\mathrm{pH}$, 전기전 도도 등과 마찬가지로 상-하층 토양의 이질성에 기인한 결과로 보인다. 즉, 하층의 이화학 변화가 상층에 미치는 영향이 미미했던 것으로 판단된다. 복토층 두께에 따른 철과 망간의 경시변화는 하층에 제강슬래그로 안정화 처 리했을 경우의 철을 제외하면 모니터링 중후반 경과시점 부터 $40 \mathrm{~cm}$ 복토 $>20 \mathrm{~cm}$ 복토의 경향을 보였다. 특히, 망간에서 그 경향이 두드러지는데 이는 $40 \mathrm{~cm}$ 복토층 내 산화환원전위 감소의 영향이 컸다고 할 수 있다.

칼슘은 컬럼 하층 중 제강슬래그를 혼합한 조건(BL 20, $\mathrm{BL} 40$ )에서 타조건 대비 높은 농도를 보였다. 본 조건에 서 나타난 칼슘은 안정화제인 제강슬래그로부터 용탈된 것으로 볼 수 있다. 복토를 한 상황에서 상-하층간 칼슘

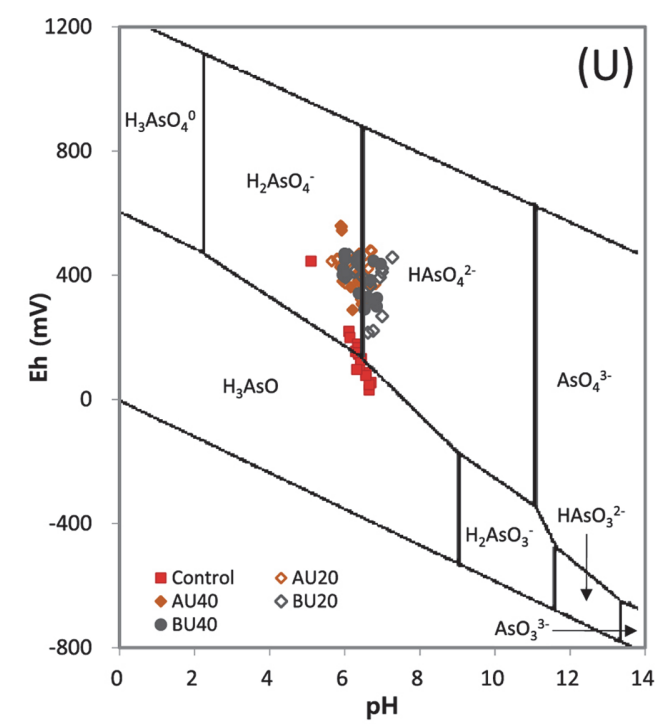

농도의 경시변화는 뚜렷한 유사성을 보이지 않았다. 이 역시 컬럼 상-하층 토양의 이질성에 기인한 것으로 하층 의 이화학 변화가 상층에 미치는 영향이 제한적이었던 것으로 판단된다. 복토 두께에 따른 칼슘 농도는 모니터 링 중후반 경과시점부터 $40 \mathrm{~cm}$ 복토 $>20 \mathrm{~cm}$ 복토의 경 향을 보였다. 특히, 복토층에서 나타난 칼슘의 변화는 망 간과 상당히 유사한 결과를 나타내었다. 이는 복토 두께 증가에 따른 산화환원전위의 감소폭 증가, 이에 따라 용 출이 증가한 망간이온 $\left(\mathrm{Mn}^{2+}\right)$ 이 토양입자 표면의 칼슘과 이온교환을 했기 때문으로 판단된다(He et al., 2010).

원토양의 오염물질인 비소는 컬럼 하층에서 안정화 처 리유무에 따른 농도변화가 확인되지 않았다. 아울러 컬 럼 상층에서는 대조구를 제외한 나머지 4 개 조건의 컬럼 에서 모두 불검출되었다. 따라서 안정화 유무, 복토두께 에 따른 토양개량복원의 효과는 토양용액 분석결과보다 는 식물체 분석결과를 통해 확인해야 할 것이다. 다만, Fig. 4에 나타낸 바와 같이 $\mathrm{pH}$ 와 산화환원전위를 바탕으 로 토양용액 내 존재할 수 있는 비소의 종(species)을 추 정한 결과 컬럼 상층은 안정화처리 유무나 복토두께에 상관없이 대부분 +5 가의 비산(arsenate)으로 존재하였다. 컬럼 하층에서는 제강슬래그 내 산화철의 영향으로 산화 환원전위가 높게 나타났던 안정화 처리층(BL 20, BL 40) 을 제외하면 나머지 조건에서 나타난 비소의 형태는 +3 가의 아비산(arsenite)이었다. 아비산의 경우 이동성이 높 은 것으로 알려졌다(Cox, 1995; Nakamura and Katou, 2013; Han et al., 2013). 따라서 경작층에서의 보다 완전 한 비소 이동성 제어를 위해서는 하부 오염토층의 안정 화 처리 시 철이 함유된 안정화제의 사용도 타당할 것이다.

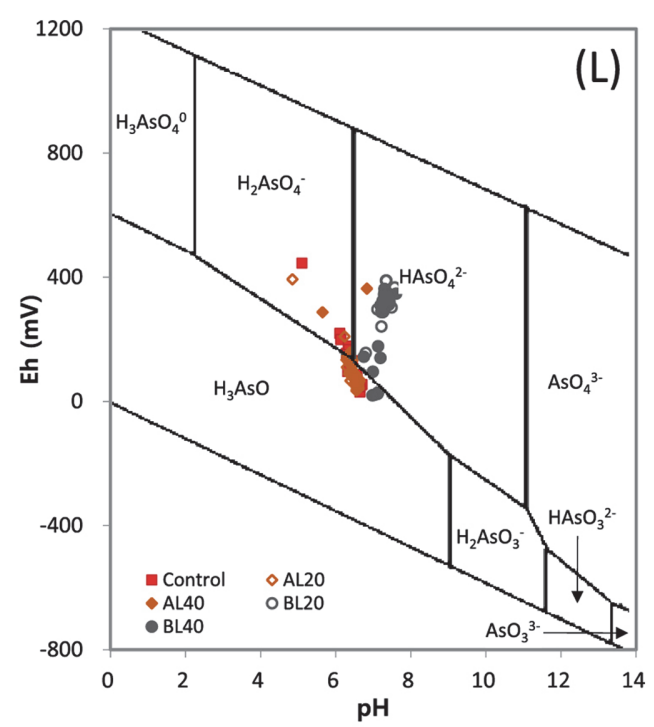

Fig. 4. The species of As in soil solution ((U) upper layer, clean soil cover; (L) lower layer, contaminated or stabilized layer). 


\section{3. 벼 비소 함량}

Fig. 5는 컬럼실험 종료시점에서 채취한 벼(뿌리 및 쌀 알)의 비소 농도 분석결과를 나타낸 것이다. 뿌리와 쌀알 로 구분하여 분석한 이유는 해당 부위가 토양개량복원 효과를 객관적으로 나타낼 수 있을 것으로 판단했기 때 문이다. 뿌리는 토양오염 물질의 축적(전이)이 가장 먼저 일어나는 곳으로 토양 내 오염물질의 이동성 저감효과를, 쌀알은 인체에 유입되는 가식부로서 인체위해성 저감효 과 발현유무를 판단할 수 있다. 줄기와 잎사귀는 분석대 상에서 제외했는데, 지상부로 이행된 농도는 토양 내 농 도와의 상관성이 떨어진다는 기존의 연구(Koh et al., 2017; Kwon et al., 2013)를 참조한 것이었다.

벼 뿌리의 비소 함량은 두께 $40 \mathrm{~cm}$ 의 복토층에서 성 장했을 때 하부 오염토양의 안정화처리에 상관없이 비소 함량 $1.6 \mathrm{mg} / \mathrm{kg}$ 전후의 일정한 수준을 보였다. 이는 원 토양(대조구)에서 성장한 벼와 비교했을 때 $98 \%$ 감소한 것이었다. 따라서 $40 \mathrm{~cm}$ 복토 시에는 하부 오염토의 오 염물질이 경작층(복토층)에 미치는 영향이 제한적이거나 미미한 수준일 것으로 판단된다. 아울러 이러한 결과는 표토의 오염 없이 심토만 오염된 농경지를 대상으로 하 는 토양개량-복원 사업지에 참조할 필요가 있다. 즉, 농 작물 관점에서 본다면 현행 $40 \mathrm{~cm}$ 복토보다는 안정화처 리 없이 $20 \mathrm{~cm}$ 복토만으로도 비소의 전이감소를 이룰 수 있을 것으로 판단된다. 아울러 벼 뿌리의 성장범위 역시 지표면으로부터 $20 \mathrm{~cm}$ 이내 구간이므로(Kirk et al., 2014), 오염토층과의 직접적인 접촉에 따른 오염물질의 흡수도 제한적일 것으로 보인다.

벼 뿌리의 비소 함량을 통한 안정화 처리효과는 $20 \mathrm{~cm}$ 복토조건에서 확인되었다. 오염토양의 안정화 처리 없이 $20 \mathrm{~cm}$ 두께의 복토만을 한 경우 대조구 대비 $58 \%$ 의 전 이감소 효과를 얻을 수 있었다. 그러나 안정화 처리 후 동일 두께의 복토를 하면 $80 \%$ 에 가까운 전이감소 효율
을 나타내었다. 즉 안정화 처리를 통해 $22 \%$ 포인트의 추 가 전이감소 효과를 얻을 수 있었다. $80 \%$ 가까운 전이감 소 효율은 안정화 처리 후 $40 \mathrm{~cm}$ 복토를 통해 얻은 $98 \%$ 효율보다는 낮은 수치이다. 그러나 복토재의 사용량 감 소측면에서 보면 충분히 효율적이라고 판단할 수 있을 것이다. 일정 간격으로 채취한 토양용액의 모니터링 과 정에서 확인한 비소의 농도변화에서는 안정화 효과를 쉽 게 확인할 수 없었다. 그러나 본 실험결과와 같이 토양 의 영향을 직접적으로 받는 식물체 분석을 통해 안정화 효과확인이 가능하다. 이는 농경지 안정화 효과검증을 위 한 검체로서 식물체를 우선적으로 선정하는 것이 타당함 을 언급한 Koh et al.(2013)의 연구내용과 유사한 것이다. 쌀알의 경우 복토두께에 상관없이 안정화 처리유무에 따른 차이만을 보였다. 비소 농도는 안정화 처리를 하지 않은 경우 $0.3 \mathrm{mg} / \mathrm{kg}$ 전후, 안정화 처리 시 $0.15 \mathrm{mg} / \mathrm{kg}$ 전후였다. 이는 대조구와 비교했을 때 각각 $78 \%, 89 \%$ 저 감된 수치였다. 이 같은 결과는 뿌리로 유입된 오염물질 의 식물체 내 이행은 토양의 특성보다는 식물체 내 생화 학적 영향을 높게 받는다는 것을 나타낸 것이다. 즉, 식 물체 뿌리로 흡수된 비소는 지상부나 쌀알로 거의 이행 되지 않는다는 과거의 연구사례(Park et al., 2009; O' Neill, 1990)를 볼 때 본 결과 역시 각 처리조건별 뿌리로 흡수 된 비소가 제한적으로 지상부로 이행했던 것으로 판단된 다. 따라서 농경지 토양 안정화 효과의 발현유무 확인을 위해서는 식물체 가식부 이전에 뿌리의 오염물질 함량을 우선적으로 검토할 필요가 있다.

개량복원 사업을 실시한 농경지는 지속적인 사후관리 가 필요하다. 이는 관리부주의로 인해 과도한 경운작업 을 했을 경우 복토층(경작층)과 하부의 오염층이 혼합되 어 경작층 내 오염물질의 물리적 유입이 발생할 수 있기 때문이다. 특히, 복토층의 두께가 $20 \mathrm{~cm}$ 인 경우 이에 더 취약할 수 있다. 그러나 석탄광산 지역의 경우 그 오염
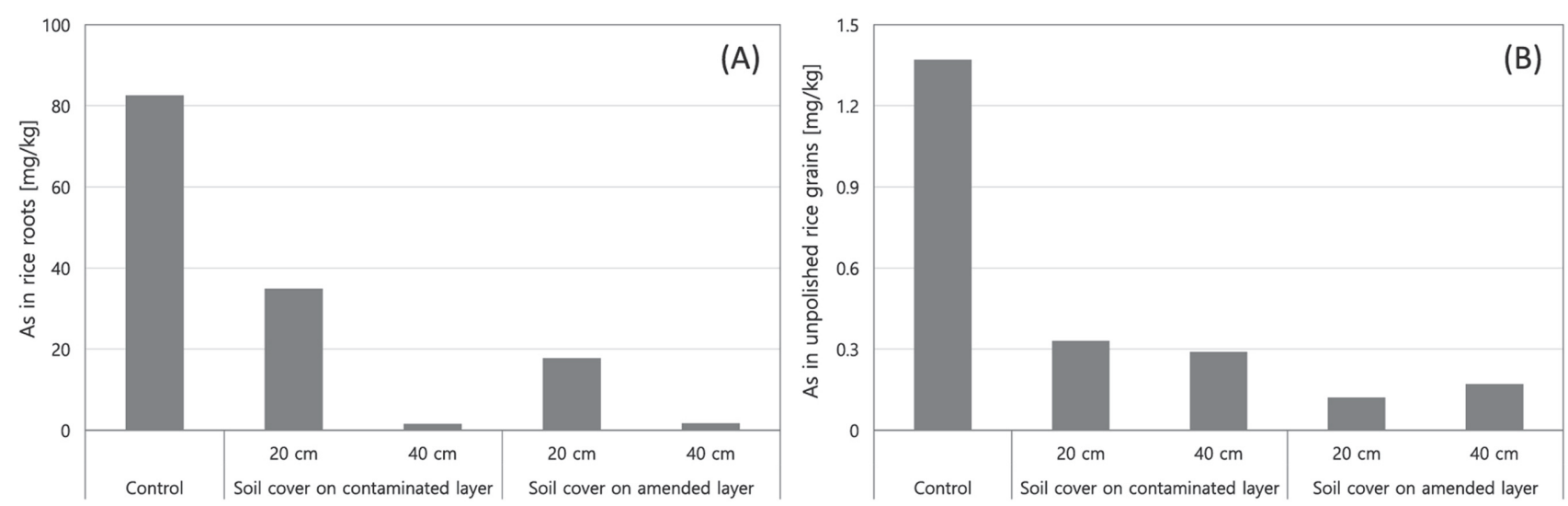

Fig. 5. As contents of rice plant ((A) rice roots; (B) unpolished rice grains). 
농도 수준이 우려기준을 경미하게 넘는 저농도 오염특성 을 가지므로 일부 관리부주의에 따른 물리적 유입이 있 더라도 농작물 전이에 미치는 영향은 높지 않을 것으로 판단된다.

\section{4. 결 론}

본 연구에서는 저농도 비소오염 특성을 가지는 폐석탄 광산지역 농경지 토양을 대상으로 토양개량·복원공법 적 용 시 복토층 두께의 감소가능성을 검토하였다. 실제 개 량조건을 모사한 담수형 컬럼실험을 통해 각 토양층(복 토층, 오염토층 또는 안정화층)의 토양용액을 모니터링하 였다. 본 모니터링 과정을 통해 복토층의 두께 변화에 따 른 복토층-원지반층(안정화층) 간 토양용액 거동영향을 확인하였고, 비소의 벼 전이농도를 통해 복토층 두께감 소 가능성을 확인하였다.

복토층별 토양용액 특성변화 모니터링 결과 대체적으 로 컬럼상-하층간 거동의 유사성은 낮은 것으로 확인되 었다. 이는 기본적으로 원지반 토양과 다른 지역을 출처 로 하는 복토재가 가지는 물리·화학적 이질성에 기인한 것으로 풀이된다. 복토 두께에 따른 각 검토인자의 경시 변화에서도 복토층 하부의 원지반층 또는 안정화층에서 발생하는 화학적 변화보다는 복도층의 물리적 두께 변화 에 따라 변화하는 ORP의 영향이 높은 것으로 확인되었 다. 대상 토양의 오염물질인 비소의 토양용액 내 농도변 화는 복토층 두께변화, 안정화제 처리여부에 따른 유의 미한 결과를 나타내지 않았다. 다만, 원지반층을 제강슬 래그로 안정화 처리했을 경우 토양 내 철 투여효과로 인 한 ORP 증가효과로 오염물질인 비소가 비산으로 존재할 가능성이 높은 것으로 나타났다. 이는 곧 오염토층(원지 반층) 비소의 이동성을 낮춤으로써 복토층으로의 이동가 능성도 감소시키고 근본적으로는 식물체로의 전이를 낮 출 수 있음을 나타낸 것이다.

모니터링 종료시점에서 채취한 벼의 뿌리를 분석결과 두께 $40 \mathrm{~cm}$ 의 복토층을 조성한 경우 안정화처리 여부에 상관없이 대조구 대비 $98 \%$ 감소한 농도를 나타내었다. 이는 곧 심토만 오염된 농경지에서는 복토층의 두께감소 가 가능한 것임을 나타낸 것이다. $20 \mathrm{~cm}$ 두께의 복토 조 건의 경우 복토층만을 조성한 조건에서 $58 \%$, 안정화 처 리후 복토한 경우 $80 \%$ 의 전이감소 효과를 얻을 수 있었 다. 특히, 안정화 처리 후 나타난 $80 \%$ 전이감소 효과는 복토재 사용량 감소측면에서 보면 충분히 효율적임을 나 타낸 것으로 볼 수 있다. 즉, 폐석탄광산 지역 내 토양오 염 우려기준을 경미하게 넘는 비소오염 농경지를 대상으
로하는 $20 \mathrm{~cm}$ 두께의 복토처리도 오염물질의 식물체 전 이감소에 충분히 효과가 있을 것으로 판단된다.

\section{사 사}

본 연구는 2020년 한국광해관리공단으로부터 기술개발 사업비를 지원받아 수행된 것임.

\section{References}

Brady, N.C. and Weil, N.N. (2014) Elements of the nature and properties of soils. Pearson Education Limited, p.358-359.

Cox, P.A. (1995) The elements on earth, Oxford University Press, Oxford, New York, Tokyo, 110p.

Han, H.J., Kim, J.Y., Lee, B.T., Kim, K.W., Kim, Y.S. and Lee, J.S. (2013) Comparative study on the characteristics of two sequential extraction methods for arsenic fractionations in the soil. J. KSMER, v.50, p.35-43.

He, Z.L., Shentu, J. and Yang, X.E. (2010) Manganese and selenium. In Hooda, P.S.(ed.) Trace elements in soils, John Wiley \& Sons, Ltd., 485p.

Jung, M.C. and Jung, M.Y. (2006) Evaluation and management method of environmental contamination from abandoned metal mines in Korea, J. KSMER, v.43, p.383-394.

Jung, Y.K., Hong, J.H., Lee, D.J., Kim, J.P., Kim, D.K. and Joo, S.D. (2008) A study on mine drainage characteristics as abandoned coal mine in Gyeongsang province, Proceedings of the Korean Geotechnical Society Conference, Gwangju, Korea, p.1440-1445.

Kim, M.S., Park, M.J., Yang, J.H. and Lee, S.H. (2019) Human health risk assessment for toxic trace elements in the Yaro mine and reclamation options. Int. J. Environ. Res. Public Health, v.16, 5077. doi: 10.3390/ijerph16245077

Kirk, G.J.D., Greenway, H., Atwell, B.J., Ismail, A.M. and Colmer, T.D. (2014) Adaptation of rice to flooded soils. In Lüttge, U., Beyschlag, W. and Cushman, J. (ed) Progress in Botany 75, Springer, Heidelberg, New York, Dordrecht, London, 223p.

Kirk, G. (2004) The biochemistry of submerged soils. John Wiley \& Sons, Ltd., p.109-112p.

Koh, I.H., Kim, E.Y., Ji, W.H., Yoon, D.G. and Chang, Y.Y. (2015a) The fate of As and Heavy metals in the flooded paddy soil stabilized by limestone and steelmaking slag, J. Soil Groundw. Environ., v.20, p.7-18.

Koh, I.H., Kim, E.Y., Kwon, Y.S., Ji, W.H., Joo, W.H., Kim, J.H., Shin, B.S. and Chang, Y.Y. (2015b) Partitioning of heavy metals between rice plant and limestone-stabilized paddy soil contaminated with heavy metals. J. Soil Groundw. Environ., v.20, p.90-103.

Koh, I.H., Kim, J.E., Kim, G.S. and Ji, W.H. (2017) Transfer of arsenic and heavy metals from soils to rice plant under different drainage conditions. J. Soil Groundw. Environ., v.22, p.12-21.

Koh, I.H., Lee, S.H., Lee, W.S. and Chang, Y.Y. (2013) Assessment 
on the transition of arsenic and heavy metal from soil to plant according to stabilization process using limestone and steelmaking slag. J. Soil \& Groundwater Env., v.18, p.63-72.

Kwon, H.H. and Nam, G.S. (2013) Mine Reclamation Engineering, DongHwa Technology Publishing Co., 27p, 268-270p.

Kwon, J.C., Jeong, S.H., Jung, M.C. and Kim, T.S. (2013) Seasonal variation and correlation between soil and crop plant of arsenic and heavy metal concentrations in paddy fields around the Yeongdae Au-Ag mine, Korea. J. KSMER, v.50, p.212-226.

Kwon, Y.S., Koh, I.H., Yang, S.C. and In, H.J. (2021) Characteristics of agricultural soil contamination in abandoned coal mine by regional river system, Proceedings of the Korean Society of Soil and Groundwater Environment Conference, Gyeongju, Korea, p.152-153.

Li, J., Dong, f., Lu, Y., Yan, Q. and Shim, H. (2014) Mechanisms controlling arsenic uptake in rice grown in mining impacted regions in south China. PLOS ONE, v.9, doi: 10.1371/ journal.pone.0108300.

Lim, J.E., Kim, K.R., Lee, S.S., Kwon, O.K., Yang, J.E. and Ok, Y.S. (2010) Stabilization of As (arsenic(V) or roxarsone) contaminated soils using zerovalent iron and basic oxygen furnace slag. J. Korean Soc. Environ. Eng., v.32, p.631-638.

Makino, T., Maejima, Y., Akahane, I., Kamiya, T., Takano, H., Fujitomi, S., Ibaraki, T., Kunhikrishnan, A. and Bolan, N. (2016) A practical soil washing method for use in a Cd-contaminated paddy field, with simple on-site wastewater treatment. Geoderma, v.270, p.3-9.

Makino, T., Takano, H., Kamiya, T., Itou, T., Sekiya, N., Inahara, M. and Sakurai, Y. (2008) Restoration of cadmium-contaminated paddy soils by washing with ferric chloride: Cd extraction mechanism abd bench-scale verification. Chemosphere, v.70, p.1035-1043.

Makino, T., Kamiya, T., Takano, H., Itou, T., Sekiya, N., Sasaki, K., Maejima, Y. and Sugahara, K. (2007) Remediation of cadmiumcontaminated paddy soils by washing with calcium chloride: Verification of on-site washing. Environ. Pollut., v.147, p.112119.

Meharg, A.A. and Zhao, F.J. (2012) Arsenic \& rice, Springer, Dordrecht, Heidelberg, London, New York, p.71-74.

MFDS (Korea Ministry of Food and Drug Safety) (2016) Korean Food Standards Codex.

NAAS (National Academy of Agricultural Science) (2010) Methods of soil chemical analysis.

Nakamura, K. and Katou, H. (2013) Arsenic and cadmium solubilization and immobilization in paddy soils in response to alternate submergence and drainage. In Selim, H.M. (ed.) Competitive sorption and transport of heavy metals in soils and geological media, CRC Press, p.379-404.

Navarro, M.C., Pérez-Sirvent, C., Martínez-Sánchez, M.J., Vidal, J., Tovar, P.J. and Bech, J. (2008) Abandoned mine sites as a source of contamination by heavy metals: A case study in a semi-arid zone. J. Geochem. Explor., v.96, p.183-193. doi: 10.1016/ j.gexplo.2007.04.011.

NIER (National Institute of Environmental Research) (2018) Korea standard methods for soil analysis.

NIER (National Institute of Environmental Research) (2019) Korea standard methods for water analysis.

O’Neill, P. (1990) Arsenic. In Alloway, B.J. (ed.) Heavy metals in soils, Blackie, Glasgow, London, 93p.

Park, S.W., Yang, J.S., Ryu, S.W., Kim, D.Y., Shin, J.D., Kim, W.I., Choi, J.H., Kim, S.L. and Saint, A.F. (2009) Uptake and translocation of heavy metals to rice plant on paddy soils in "Top-Rice" cultivation areas. Korean J. Environ. Agric., v.28, p.131-138.

Pierzynski, G.M., Sims, J.T. and Vance, G.F. (1994) Soils and environmental quality. Lewis Publishers, Boca Raton, Ann Arbor, London, Tokyo, p.229-231.

Sparks, D.L. (1995) Environmental soil chemistry. Academic Press, San Diego, New York, Boston, London, Sydney, Tokyo, Toronto, p.190-191.

Yang, J.E., Jung, J.B., Kim, J.E. and Lee, G.S. (2008) AgEnvironmental Science, CIR.

Yun, S.W., Kang, S.I., Jin, H.G., Kim, H.J. and Yu, C. (2011) Leaching characteristics of arsenic and heavy metals and stabilization effects of limestone and steel refining slag in a reducing environment of flooded paddy soil. J. Agric. Life Sci., v.45(6), p.251-263.

Zhu, X., Qi, X., Wang, H., Shi, Y., Liao, T., Li, Y., Liu, C. and Wang, X. (2014) Characterization of high-arsenic sludge in copper metallurgy plant. In Sarpenter, J.S., Bai, C., Hwang, J.Y., Ikhmayies, S., Li, B., Monteiro, S.N., Peng, Z., and Zhang, M.(ed.) Characterization of minerals, metals, and materials 2014, John Wiley \& Sons, Ltd., Hoboken, New Jersey, p.173-184. 